JKEP

Vol 5, No 2, November 2020

ISSN: 2354-6042 (Print)

ISSN : 2354-6050 $\underline{\text { (Online) }}$

\title{
Inovasi Kesehatan Terkini Sebagai Strategi Efektif Pada Manajemen Diabetes Di Masa Pandemi: Sebuah Tinjauan Literature
}

\author{
Juwi Athia Rahmini ${ }^{1}$, Dwi Kartika Rahayuningtyas ${ }^{2}$ \\ ${ }^{1}$ STIKes Binalita Sudama Medan \\ ${ }^{2}$ Poltekkes Kemenkes Jakarta 3 \\ Email :athia_r@yahoo.com
}

\author{
Artikel history \\ Dikirim, Oct $23^{\text {th }}, 2020$ \\ Ditinjau, Nov $06^{\text {th }}, 2020$ \\ Diterima, Nov $27^{\text {th }}, 2020$
}

\section{ABSTRACT}

Diabetics are increasing every year in the world, including in Indonesia. The ministry of health has carried out a solution to control diabetes, but the role of nurses as educators is not yet clearly defined, especially using technological innovations via cell phones or the web. This article aims to describe the development of technological innovations in the perspective of treating diabetes patients based on remote care using cellphone or web technology that can be used in a new adaptation period. The method used is a narrative literature review. Smartphone or web technology offers great benefits for diabetic patient care, behavior modification and education. Interactive Diabetes Diary is proven to help improve this way and is very easy to use. Diabetes management via cell phone or web is one solution for the latest nursing care services in improving the health status of diabetes patients.

Keywords: management diabetes, technology telehealth, mHealth

\begin{abstract}
ABSTRAK
Pendahuluan.Penderita diabetes semakin meningkat setiap tahun didunia termasuk di Indonesia. Pada dasarnya solusi untuk pengendalian dari penyakit diabetes telah dilakukan kementrian kesehatan, namun peran perawat sebagai edukator belum tergambar jelas terutama mengunakan inovasi teknologi melalui ponsel atau web. Artikel ini bertujuan memaparkan perkembangan inovasi teknologi dalam perspektif perawatan pasien diabetes dengan berbasis perawatan jarak jauh dengan mengunakan teknologi ponsel atau web yang dapat digunakan di masa adaptasi kebiasaan baru. Metode yang digunakan adalah Narative literature review. Hasil Teknologi ponsel pintar atau web menawarkan manfaat yang untuk perawatan, modifikasi perilaku dan pendidikan pasien diabetes seperti Glukosa Buddy terbukti membantu meningkatkan kepatuhan dan sangat mudah digunakan. Rekomendasi Manajemen diabetes melalui ponsel atau web merupakan salah satu solusi untuk pelayanan asuhan keperawatan terkini dalam meningkatkan derajat kesehatan pasien diabetes.

Kata kunci: manajemen diabetes, teknologi telehealth; mHealth
\end{abstract}




\section{PENDAHULUAN}

Diabetes adalah penyakit multisitem yang berhubungan dengan abnormal produksi insulin, kerusakan insulin atau keduanya (Lewis, 2014). Data Internasional Diabetes Federation (IDF) menunjukkan penderita diabetes mengalami peningkatan sebanyak 4 kali lipat menjadi 415 juta orang pada tahun 2015 (1 diantara 11 orang dewasa menyandang diabetes). Diperkirakan jumlah penderita diabetes akan terus meningkat sampai 642 juta jiwa pada tahun 2040. Sehingga salah satu beban pengeluaran kesehatan terbesar dunia untuk mengobati penderita diabetes berkisar $11 \%$ dari total pembelajaan langsung kesehatan dunia.

Penderita diabetes $80 \%$ berada dinegara berpenghasilan rendah dan menengah. Secara genetik wilayah Asia tenggara rentan terhadap faktor risiko menderita diabetik seperti usia, kelebihan berat badan, dan distribusi lemak. Pria berjumlah $60 \%$ dan wanita $40 \%$ meninggal sebelum berusia 70 tahun. Sekitar 1 juta orang dewasa meninggal karena peningkatan kadar gula darah dan komplikasi dari diabetes di populasi tersebut (WHO, 2016 ).

Saat ini Indonesia menempati urutan keenam dengan jumlah penderita diabetes di dunia. Diabetes menunjukkan peningkatan angka kejadian dari $5,7 \%$ (2007) menjadi 6,9\% (2013) sekitar 9,1 juta penderita di Indonesia (Rikesda, 2013). Prevalensinya cenderung meningkat, bahkan 2/3 penderita diabetes tidak mengetahui dirinya memiliki diabetes, dan terlambat untuk memeriksakan diri ke pusat pelayanan kesehatan terdekat sehingga terjadi komplikasi.

Komplikasi diabetes terjadi akibat kualitas hidup yang buruk sehingga dibutuhkan peran perawat dalam asuhan keperawatan yang efektif, disamping keikutsertaan pasien serta keluarga secara mandiri. Pendidikan kesehatan kepada pasien dan keluarga akan sangat membantu meningkatkan keikutsertaan mereka secara aktif dan mandiri (Guo et al., 2014). Karena pengelolaan diabetes memerlukan pengambilan keputusan sehari-hari untuk pemasukan makanan, tes glukosa darah, pengobatan, dan latihan (Lewis, 2014).

Oleh karena itu diperlukan solusi untuk mengatasi pengelolaan diabetes lebih lanjut yaitu dengan memanfaatkan teknologi yang berkembang saat ini dengan penggunaan ponsel pintar atau web. Pengguna ponsel lebih dari 100 juta 
saat ini di Indonesia. Menristekdikti menyebutkan angka penggunaan smarthphone di Indonesia mencapai $25 \%$ dari total penduduk (65 juta jiwa). Penelitian juga menyatakan mobile health aplication dapat digunakan pada seluruh aspek kehidupan manusia dan penggunaannya dapat membantu mengontrol atau mengendalikan penyakit kronis seperti diabetes (Brzan, Rotman, Pajnkihar, 2016).

Sementara itu, Pandemi Covid 19 membuat pasien diabetes berisiko tinggi terinfeksi sehingga pasien diharapkan menghindari kontak langsung dari keramaian dan berdiam diri dirumah. Akhirnya dukungan pada pasien diabetes melalui ponsel atau video menjadi perhatian utama bagi komunitas diabetes (Zai, Cai, Sun., 2020).

Dengan fenomena tersebut kajian ini bertujuan memaparkan potensi ponsel atau web yang memberikan manfaat perawatan, modifikasi perilaku dan pendidikan kesehatan pasien diabetes secara jarak jauh. Sehingga pentingnya kajian ini untuk menambah pengetahuan dan informasi agar perawat mulai berinovasi melalui teknologi dalam memberikan asuhan keperawatan manajemen diabetes yang diharapkan mecegah komplikasi lebih lanjut, meningkatkan kualitas hidup pasien dan menekan biaya perawatan pada masa adaptasi kebiasaan baru ini.

\section{METODE}

\section{Desain Studi}

Penulisan ini merupakan narative literature review, yang memberikan pemahaman terhadap topik yang sedang dipelajari, namun tidak melalui tahap sistematik dalam pencarian pustaka atau materi yang digunakan (Pare et al., 2014). Penulis melakukan pencarian secara non sistematik atau acak melalui berbagai sumber literatur resmi dan dipercaya tentang ponsel atau web tentang manajemen diabetes. PubMed, Google scholar, dan Lib UI meruapakan salah satu pilihan sebagai sumber pustaka. Literature dibatasi dari tahun 20010- 2020, dengan tipe jurnal open access dengan kata kunci "Mobile Application for Diabetes Management, Telehealth in nursing manajemen diabetes, Telemonitoring Diabetes in nursing, Technology in Diabetes Smartphone Base, Mobile Application Dietary Management Diabetes, dan Glucose Buddy. Penulisan artikel ini menggunakan 8 jurnal dalam pembahasannya. Protokol yang dipakai dalam literature tersebut telah disetujui oleh Komite Etika setempat. 


\section{Analisis Data}

Penulis mengumpulkan sumber data dari bulan Juli 2018 -November 2020. Seluruh dokumen dikumpulkan dan ditelaah bersama-sama. Diskusi dilakukan sebanyak 6 kali sepanjang bulan AprilNovember 2020 melalui tatap nuka dan daring selama kurang lebih 2 jam, diskusi juga berlanjut melalui email dan whatsapp untuk membahas, menganaslisi secara detail kajian mulai dari pendahuluan sampai kesimpulan. Kriteria Artikel yang dipilih adalah artikel asli yang mengevaluasi studi klinis penggunaan ponsel pada pasien diabetes dari Italia, Amerika Serikat, kemudian disesuaikan dengan tujuan dari kajian ini. Akhirnya disepakati bahwa data yang digunakan telah tervalidasi.

\section{HASIL DAN PEMBAHASAN}

Salah satu pendekatan inovatif yang berpotensi mampu menangani manajemen diabetes dan pencegahan komplikasi diabetes adalah aplikasi ponsel manajemen diabetes, modifikasi perilaku dan pendidikan kesehatan pasien diabetes (David dan Raifullah, 2017). Aplikasi ini menggunakan ponsel atau web sebagai perangkat keras komunikasi dan dokumentasi yang terintegrasi antar tim pelayanan kesehatan (Gund et al., 2013). American Association of Clinical Endocrinologist (AACE) dan the American Diabetes Association (ADA) juga menyatakan teknologi ponsel kesehatan (mHealth) harus memliki fitur pendukung kemandirian bagi pasien dan petugas kesehatan.

\section{Aplikasi teknologi Manajemen diabetes:}

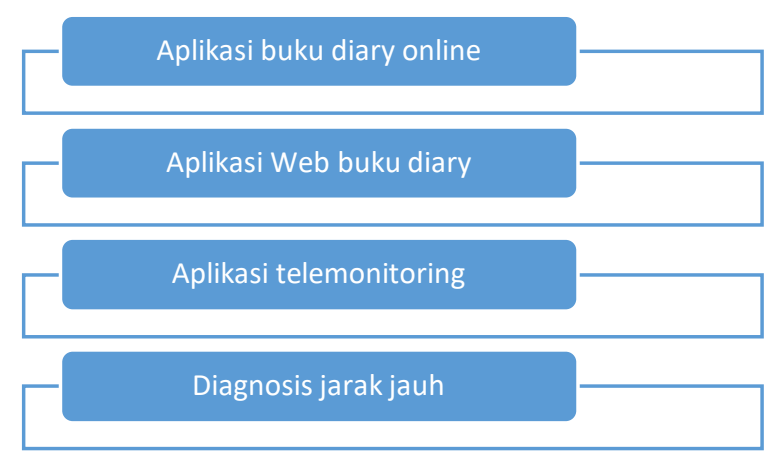

\section{Gambar 1. Aplikasi Teknologi Manajemen Diabetes (David dan Raifullah, 2017).}

Pada kajian ini didapatkan 4 artikel yang sesuai dengan aplikasi teknologi manajemen diabetes yang terlampir pada tabel dibawah ini 
Tabel 1. Aplikasi Teknologi manajemen Diabetes

\begin{tabular}{|c|c|c|c|c|c|c|c|}
\hline No & Author & Tahun & Judul & Tujuan & Metode & Hasil & Kesimpulan \\
\hline 1. & $\begin{array}{l}\text { Rossi et } \\
\text { all. }\end{array}$ & 2013 & $\begin{array}{l}\text { Impact of the } \\
\text { "Diabetes } \\
\text { Interactive } \\
\text { Diary" (DID) } \\
\text { Telemedicine } \\
\text { System on } \\
\text { Metabolic } \\
\text { Control, Risk } \\
\text { of } \\
\text { Hypoglycemia, } \\
\text { and Quality of } \\
\text { Life: A } \\
\text { Randomized } \\
\text { Clinical Trial } \\
\text { in Type } 1 \\
\text { Diabetes }\end{array}$ & $\begin{array}{l}\text { Membandin } \\
\text { gkan } \\
\text { efektivitas } \\
\text { DID versus } \\
\text { perawatan } \\
\text { biasa dalam } \\
\text { pengendalia } \\
\text { n metabolik, } \\
\text { hipoglikemia } \\
\text { kualitas dan } \\
\text { hidup. }\end{array}$ & $\begin{array}{l}\text { Pasien dengan diabetes } \\
\text { tipe 1, yang } \\
\text { sebelumnya } \\
\text { pernah tidak } \\
\text { tentang penghitungan } \\
\text { karbohidrat (, diacak } \\
\text { mengunakan DID } \\
\text { (Grup A; } \mathrm{n}=63) \text { dan } \\
\text { (Grup B; n }=64 \text { ). } \\
\text { Model regresi linier } \\
\text { hierarki umum untuk } \\
\text { pengukuran berulang } \\
\text { diterapkan untuk } \\
\text { membandingkan } \\
\text { perubahan antar } \\
\text { kelompok. dengan } \\
\text { menggunakan model } \\
\text { regresi Poisson. }\end{array}$ & 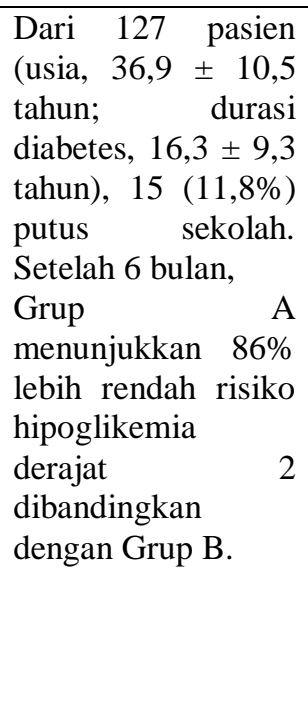 & $\begin{array}{l}\text { DID } \\
\text { mengurangi } \\
\text { risiko } \\
\text { hipoglikemia } \\
\text { sedang / berat. }\end{array}$ \\
\hline 2 & $\begin{array}{l}\text { Block } \\
\text { et al }\end{array}$ & 2015 & $\begin{array}{l}\text { Diabetes } \\
\text { Prevention and } \\
\text { Weight Loss } \\
\text { with a Fully } \\
\text { Automated } \\
\text { Behavioral } \\
\text { Intervention by } \\
\text { Email, Web, } \\
\text { and Mobile } \\
\text { Phone: A } \\
\text { Randomized } \\
\text { Controlled Among } \\
\text { Trial Alth } \\
\text { Persons with } \\
\text { Prediabetes }\end{array}$ & $\begin{array}{l}\text { Mengevalua } \\
\text { si } \\
\text { keefektifan } \\
\text { intervensi } \\
\text { perilaku } \\
\text { berbasis } \\
\text { algoritma } \\
\text { yang } \\
\text { sepenuhnya } \\
\text { otomatis } \\
\text { untuk } \\
\text { pencegahan } \\
\text { diabetes. } \\
\text { Alive-PD, } \\
\text { melalui } \\
\text { Web, } \\
\text { Internet, } \\
\text { telepon } \\
\text { seluler, dan } \\
\text { panggilan } \\
\text { telepon } \\
\text { otomatis. }\end{array}$ & $\begin{array}{l}\text { Alive-PD } \\
\text { mendukungan perilaku } \\
\text { yang disesuaikan untuk } \\
\text { peningkatan aktivitas } \\
\text { fisik, kebiasaan makan, } \\
\text { dan faktor-faktor } \\
\text { seperti penurunan berat } \\
\text { badan, stres, dan tidur. } \\
\text { Percobaan secara acak } \\
\text { menugaskan } 339 \text { orang } \\
\text { untuk intervensi Alive- } \\
\text { PD (n = 163) atau } \\
\text { kelompok kontrol } \\
\text { perawatan biasa daftar } \\
\text { tunggu } 6 \text { bulan (n = } \\
\text { 176). }\end{array}$ & 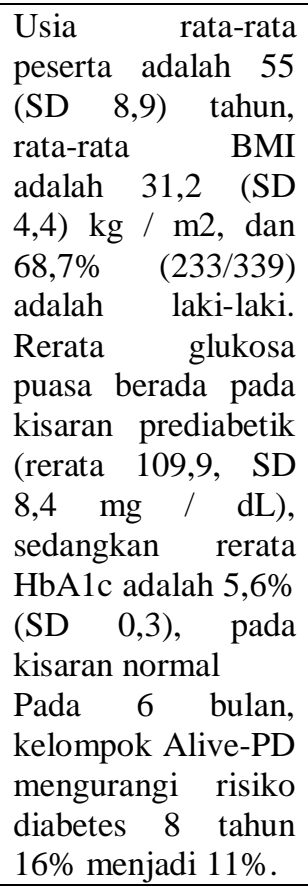 & $\begin{array}{l}\text { Alive-PD } \\
\text { meningkatkan } \\
\text { kontrol } \\
\text { glikemik, berat } \\
\text { badan, BMI, } \\
\text { lingkar } \\
\text { pinggang, rasio } \\
\text { TG / HDL, dan } \\
\text { risiko diabetes. }\end{array}$ \\
\hline 3 & Warren & 2018 & $\begin{array}{l}\text { Effect of } \\
\text { telemonitoring } \\
\text { on the } \\
\text { glycemic load } \\
\text { control and } \\
\text { health care } \\
\text { costs in type } 2 \\
\text { diabetes: A } \\
\text { randomized } \\
\text { controlled trial }\end{array}$ & $\begin{array}{l}\text { menguji } \\
\text { pengaruh } \\
\text { intervensi } \\
\text { telehealth } \\
\text { pada } \\
\text { pengendalia } \\
\text { n diabetes } \\
\text { tipe } 2 \text { dan } \\
\text { selanjutnya } \\
\text { potensi } \\
\text { penghemata } \\
\text { n biaya } \\
\text { untuk sistem } \\
\text { kesehatan }\end{array}$ & $\begin{array}{lr}\text { Uji coba prospektif } \\
\text { acak terkontrol ini } \\
\text { mengacak } & \text { orang } \\
\text { dewasa } & \text { dengan } \\
\text { diabetes tipe } 2 \text { untuk } & \text { (diabetes } \\
\text { intervensi } & \text { (dias) } \\
\text { program) atau biasa) } \\
\text { Kelompok intervensi } \\
\text { menerima perawatan } \\
\text { diabetes tambahan dari } \\
\text { koordinator melalui } \\
\text { monitor dari rumah } \\
\text { yang merekam } \\
\text { pengukuran klinis. }\end{array}$ & $\begin{array}{l}\text { Hasil dari } 63 \\
\text { peserta dari masing- } \\
\text { masing kelompok } \\
\text { studi dianalisis. } \\
\text { HbA1c pada } \\
\text { kelompok } \\
\text { intervensi menurun } \\
\text { dari a } \\
\text { median } 68 \text { mmol / } \\
\text { mol }(8,4 \%) \text { sampai } \\
58 \mathrm{mmol} / \text { mol } \\
(7,5 \%) \text {, dan tetap } \\
\text { tidak berubah. }\end{array}$ & $\begin{array}{l}\text { Ada manfaat } \\
\text { yang bermakna } \\
\text { secara klinis } \\
\text { dan signifikan } \\
\text { secara statistik } \\
\text { dari intervensi } \\
\text { telehealth } \\
\text { dengan biaya } \\
\text { lebih rendah. }\end{array}$ \\
\hline
\end{tabular}




\begin{tabular}{|c|c|c|c|c|c|c|c|}
\hline No & Author & Tahun & Judul & Tujuan & Metode & Hasil & Kesimpulan \\
\hline 4 & $\begin{array}{l}\text { Kumar } \\
\text { et al. }\end{array}$ & 2012 & $\begin{array}{l}\text { Teleophthalmo } \\
\text { logy } \\
\text { assessment of } \\
\text { diabetic } \\
\text { retinopathy } \\
\text { Fundus } \\
\text { images: } \\
\text { Smartphone } \\
\text { vs. standard } \\
\text { office } \\
\text { computer } \\
\text { workstation }\end{array}$ & $\begin{array}{l}\text { Untuk } \\
\text { mengevaluas } \\
\mathrm{i} \\
\text { penggunaan } \\
\text { Ponsel } \\
\text { cerdas } \\
\text { vs.Komputer } \\
\text { untuk } \\
\text { menilai } \\
\text { gambar } \\
\text { fundus dari } \\
\text { diabetes } \\
\text { pasien } \\
\text { retinopati }\end{array}$ & $\begin{array}{lr}\text { Gambar } & \text { pasien } \\
\text { diperoleh } & \text { dengan } \\
\text { menggunakan } & \text { kamera } \\
\text { non-mydriatic } & \text { itu } \\
\text { ditransmisikan } & \text { dengan } \\
\text { data medis 20 } & \text { bermil- } \\
\text { mil jauhnya } & \text { melalui } \\
\text { komputer workstation } \\
\text { dan melalui iPhone. } \\
\text { Dua dokter mata secara } \\
\text { mandiri } \\
\text { membandingkan } \\
\text { gambar oftalmik ang } \\
\text { dikirimkan }\end{array}$ & $\begin{array}{l}\text { Gambar oftalmik } \\
\text { ditransmisikan } \\
\text { melalui keduanya } \\
\text { ponsel pintar dan } \\
\text { Internet sama } \\
\text { kualitasnya. }\end{array}$ & $\begin{array}{l}\text { Gambar } \\
\text { kualitas iPhone } \\
\text { itu mendapat } \\
\text { penilai lebih } \\
\text { baik oleh } \\
\text { dokter mata } \\
\text { dalam } \\
\text { mendiagnosis } \\
\text { gambar fundus } \\
\text { dari diabetes } \\
\text { pasien } \\
\text { retinopati }\end{array}$ \\
\hline
\end{tabular}

Aplikasi berbasis ponsel diary (buku catatan harian) dalam kajian ini adalah Diabetes Diary Interaktif (DID) yang dapat menghitung glukosa, total asupan karbohidrat, dan penyaranan dosis penyuntikan insulin. Aplikasi ini memungkinkan pasien mengirim data nilai glukosa, asupan karbohidrat ke tenaga kesehatan melalui sms. Pasien menyatakan sistem ini membantu dan sangat mudah digunakan (Rossi et al, 2009). Penelitian terkait DID pada 127 pasien selama 6 bulan terbukti mengurangi risiko hipoglikemia. Perawatan menjadi efektif, hemat, meningkatkan kualitas hidup. DID mampu mengidentifikasi jika terjadi hiperglikemik (Rossi et al, 2013).

Aplikasi kedua adalah Alive-PD dapat diakses oleh pasien dan tenaga kesehatan, yang menunjukkan tingkat kepatuhan pasien untuk mencegah diabetes. Aplikasi ini terhubung melalui email minggu yang menyarankan informasi yang dilakukan dan ditautkan ke Web. Aplikasi ini disertai pelacakan, pembinaan dan dukungan sosial dari tim kesehatan. Alive-PD terbukti meningkatkan kontrol glikemik, berat badan, lingkar pinggang sehingga alat ini bermanfaat untuk prediabetes (Block et al, 2015).

Aplikasi selanjutnya adalah telemonitoring glikemik. Pasien dimonitordari rumah dengan mencatat kadar glukosa, diet dan aktifitas olah raga setiap hari melalui ponsel. Telemonitoring ini terbukti meminimalkan biaya perawatan, dan efek positif dari monitoring adalah perubahan signifikan nilai HbA1c. Bahkan telehealth diklaim menghemat biaya, menjangkau penderita pradiabetes serta kelompok berisiko lainnya. dan menghasilkan manfaat kesehatan yang lebih besar dibandingkan dengan perawatan biasa (Warren, 2018).

Aplikasi terakhir pada manajemen diabetes adalah diagnosis jarak jauh. Aplikasi ini 
mengevaluasi dan mengkaji gambaran fundus dari pasien dengan retinopati Gambaran mata pasien dengan menggunakan non midriatic kamera ditransmisikan dengan 20 mil data medis melalui komputer dan iphone. Dua dokter ahli mata membandingkan kedua gambar tersebut. Gambaran opthalmic harus menggunakan kualitas yang terbaik dan mengunakan tehnik berpasangan yang tepat untuk disetiap bola mata, sehingga dari gambar tersebut dokter melihat kualitas iphone lebih baik (Kumar, 2012 ).

Menurut David dan Raifullah (2017) terdapat 3 aplikasi tentang aplikasi teknologi untuk memodifikasi perilaku pasien.

\section{Monitor perilaku pasien}

\section{Monitoring ketaatan pasien}

\section{Dukungan perawatan diri pasien}

\section{Gambar 2. Aplikasi Modifikasi Manajemen Diabetes}

Aplikasi teknologi selanjutnya dengan cara monitoring perilaku pasien diabetes. Penelitian dilakukan pada remaja DM tipe 1 usia 14-18 tahun tinggal dengan keluarga, minimal bersama salah satu orang tua, untuk diwawancara. Kemudian Informasi tentang tingkah laku dan kebiasaan dikumpulkan dari masing orang tua dan remaja. Penelitiannya ini menggunakan ponsel untuk sms dan terpasang Glukosameter diberikan ke pasien untuk memonitor glukosa serta memantau perilaku pasien. Penelitian ini menunjukkan terjadi penurunan $\mathrm{HbA} 1 \mathrm{C}$ dan perbaikan dalam pengelolaan manajemen diri (self management) terjadi secara signifikan (Carroll et all, 2011).

Aplikasi lain yang memodifikasi pasien dengan menggunakan ponsel glukometer yang tehubung ke online database sistem manajemen ketaatan perilaku dan pelayanan konsultasi. Pasien dan keluarga dapat berkomunikasi melalui database online sistem manajemen perilaku dengan menggunakan pesan pribadi dan sms. Aplikasi ini didukung layanan kosultan pribadi dan pelayanan manajemen perilaku pasien diabetes. Penelitian aplikasi ini terbukti menurun level HbA1c dan 
peningkatan pemantaun glukosa (Chen, 2013 ).

Aplikasi terakhir adalah dukungan perawatan diri pasien. Ponsel pintar digunakan sebagai intervensi untuk mengakses buku harian dan situasi timbal balik seorang individu. Pasien diminta untuk mencatat pola perilaku makanan, pengobatan, aktifitas fisik, dan emosi 3 kali sehari, Pasien melaporkan intervensi sangat berarti dan mendukung pengobatan. Pasien melaporkan terjadi perubahan gaya hidup (Nes et al, 2012 ). 
Tabel 2. Aplikasi Teknologi untuk memodifikasi perilaku pasien

\begin{tabular}{|c|c|c|c|c|c|c|c|}
\hline No & Author & Tahun & Judul & Tujuan & Metode & Hasil & Kesimpulan \\
\hline 1 & $\begin{array}{l}\text { Carroll } \\
\text { et al }\end{array}$ & 2011 & $\begin{array}{l}\text { Contracting and } \\
\text { monitoring } \\
\text { relationships for } \\
\text { adolescents with } \\
\text { type } \\
1 \text { diabetes: a pilot } \\
\text { study }\end{array}$ & $\begin{array}{l}\text { Untuk menilai efek } \\
\text { kombinasi dari } \\
\text { kontrak perilaku dan } \\
\text { pemantauan glukosa } \\
\text { dengan ponsel, profil } \\
\text { dan pola perilaku } \\
\text { pasien remaja. }\end{array}$ & $\begin{array}{l}\text { Remaja dengan diabetes tipe } 1 \text { berusia antara } \\
14 \text { dan } 18 \text { tahun, tinggal dengan setidaknya } \\
\text { satu orang tua yang ikut berpartisipasi. Semi- } \\
\text { terstruktur wawancara pribadi digunakan } \\
\text { untuk mengumpulkan informasi dari masing- } \\
\text { masing pasangan orang tua-remaja. Glukosa } \\
\text { ponsel meteran diberikan kepada pasien. } \\
\text { Ponsel digunakan mengirim SMS untuk } \\
\text { mengirim informasi yang kepatuhan perilaku. } \\
\text { Orang tua diminta untuk kurangi frekuensi } \\
\text { menanyai kondisi anaknya atau perilaku yang } \\
\text { sedang dipantau. }\end{array}$ & $\begin{array}{lll}\text { Penurunan } & \text { yang } & \text { signifikan } \\
\text { HbA1c } & \text { dan } & \text { kepatuhan } \\
\text { perilaku } & & \end{array}$ & $\begin{array}{l}\text { Kontrak dan } \\
\text { monitor perilaku } \\
\text { terbukti } \\
\text { meningkatan } \\
\text { manajemen diri } \\
\text { remaja diabetes }\end{array}$ \\
\hline 2 & $\begin{array}{l}\text { Chen } \\
\text { et al. }\end{array}$ & 2013 & $\begin{array}{l}\text { Evaluating self- } \\
\text { management } \\
\text { behaviours of } \\
\text { diabetic patients } \\
\text { in a telehealth } \\
\text { care } \\
\text { programme: } \\
\text { longitudinal study } \\
\text { over } 18 \text { months }\end{array}$ & $\begin{array}{l}\text { Untuk menyelidiki } \\
\text { pola perilaku pasien } \\
\text { diabetes } \\
\text { menggunakan } \\
\text { Telehealthcare } \\
\text { program dan } \\
\text { efek pada glikemik } \\
\text { kontrol }\end{array}$ & $\begin{array}{l}\text { Pasien dalam kelompok intervensi disediakan } \\
\text { telekomunikasi ponsel glukometer, self- } \\
\text { manajemen diabetes online sistem, dan } \\
\text { telekonsultan layanan diabetes. Pasien dan } \\
\text { keluarga dapat berkomunikasi melalui self- } \\
\text { manajemen diabetes online sistem } \\
\text { menggunakan pesan internal layanan atau } \\
\text { SMS. Layanan telekonsultan mendukung } \\
\text { manajemen diri pasien diabetes }\end{array}$ & $\begin{array}{l}\text { Lima perilaku pasien yaitu } \\
\text { mengalami perubahan } \\
\text { signifikan menjadi aktif, } \\
\text { sehat,diet diatur, minum } \\
\text { obat tepat waktu, koping } \\
\text { yang sehat dan pemecahan } \\
\text { masalah yang tepat pada } \\
\text { pembelajaran ditingkatkan } \\
\text { akhir. Tingkat HbAlc } \\
\text { menurun secara signifikan } \\
\text { dan juga ada peningkatan } \\
\text { pemantauan glukosa. }\end{array}$ & $\begin{array}{lr}\text { Telehealth } & \text { care } \\
\text { terbukti } & \text { membawa } \\
\text { dampak } & \text { positif } \\
\text { ketaatan } & \text { perilaku } \\
\text { pasien } & \text { dan } \\
\text { penurunan } & \text { nilai } \\
\text { HbAlc. } & \end{array}$ \\
\hline 3 & $\begin{array}{l}\text { Nes } \\
\text { et al. }\end{array}$ & 2012 & $\begin{array}{l}\text { The development } \\
\text { and feasibility of } \\
\text { a web based } \\
\text { intervention with } \\
\text { diaries } \\
\text { situational and } \\
\text { feedback via } \\
\text { Smartphone to } \\
\text { support self } \\
\text { management in } \\
\text { patients with } \\
\text { diabetes type } 2\end{array}$ & $\begin{array}{l}\text { Untuk menguji } \\
\text { kelayakan } \\
\text { menggunakan } \\
\text { Smartphone berbasis } \\
\text { web dengan } \\
\text { buku harian di } \\
\text { kelola sendiri oleh } \\
\text { pasien diabetes }\end{array}$ & $\begin{array}{l}\text { Intervensi penggunaan ponsel pintar dengan } \\
\text { mengaktifkan akses kebuku harian berbasis } \\
\text { web dan menulis umpan balik secara mandiri. } \\
\text { Pesertanya diminta untuk meuliskan makan, } \\
\text { kepatuhan perilaku, pengobatan, kegiatan } \\
\text { fisik dan emosi dalam tiga kali sehari } \\
\text { menggunakan ponsel. }\end{array}$ & $\begin{array}{l}\text { Pasien melaporkan bahwa } \\
\text { intervensi itu mendukung } \\
\text { dan berarti. Sebagian besar } \\
\text { peserta melaporkan } \\
\text { perubahan gaya hidup } \\
\text { positif. }\end{array}$ & $\begin{array}{l}\text { Diary via } \\
\text { smartphone terbukti } \\
\text { memberikan efek } \\
\text { positif pada pasien } \\
\text { diabetes. }\end{array}$ \\
\hline
\end{tabular}


Menurut David dan Raifullah (2017) Aplikasi teknologioasien diabetes adalah Pendidikan pasien. Aplikasi smartphone dapat digunakan Glucose Buddy yang tersedia secara gratis. Aplikasi manajemen diabetes iPhone yang digunakan pada diabetes tipe 1dengan cara mengumpulkan informasi pasien dan mengiirimkan umpan balik SMS. Penelitian dengan menggunakan Glucose Buddy terbukti signifikan perubahan nilai HbA1c, akan tetapi kualitas hidup dan perawatan diri aktivitas tidak membaik (Kirwan et al., 2013).

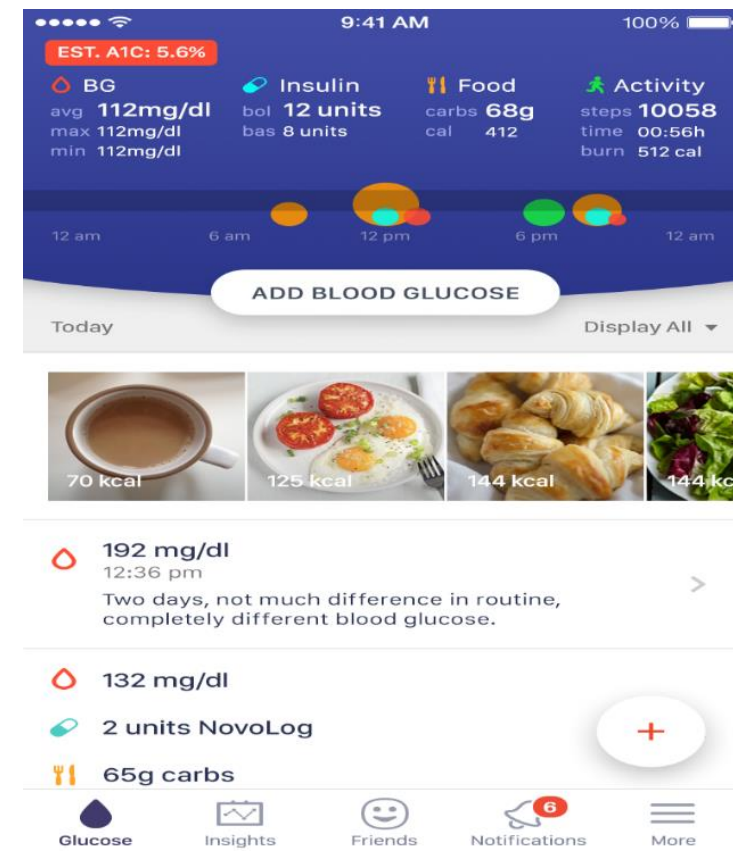

Gambar 3. Aplikasi Glucose Buddy 
Tabel 3. Aplikasi Teknologi Pendidikan Pasien

\begin{tabular}{|c|c|c|c|c|c|c|c|}
\hline No & Author & Tahun & Judul & Tujuan & Metode & Hasil & Kesimpulan \\
\hline 1 & $\begin{array}{l}\text { Kirwan } \\
\text { et al }\end{array}$ & 2013 & $\begin{array}{l}\text { Diabetes self } \\
\text { management } \\
\text { Smartphone } \\
\text { application } \\
\text { for adults } \\
\text { with type } 1 \\
\text { diabetes: } \\
\text { randomised } \\
\text { controlled } \\
\text { trial }\end{array}$ & $\begin{array}{lr}\text { Untuk } & \text { memeriksa } \\
\text { efektivitas } & \text { aplikasi } \\
\text { Smartphone } \text { (Glukosa } \\
\text { Buddy) digabungkan } \\
\text { dengan umpan balik } \\
\text { SMS dari konsultan } \\
\text { diabetes r tentang } \\
\text { glikemik hontrol, } \\
\text { kualitas hidup dan } \\
\text { perawatan diri. }\end{array}$ & $\begin{array}{l}\text { Pasien diacak menjadi dua } \\
\text { gorup yaitu grup aplikasi } \\
\text { telepon dan kelompok kontrol } \\
\text { (perawatan biasa). Pasien } \\
\text { dalam kelompok intervensi } \\
\text { menerima pesan teks } \\
\text { mingguan untuk } 6 \text { bulan dan } \\
\text { semua pasien ditindaklanjuti } \\
\text { selama } 3 \text { bulan setelah masa } \\
\text { pengobatan. }\end{array}$ & $\begin{array}{l}\text { Ponsel pintar } \begin{array}{l}\text { intervensi } \\
\text { aplikasi menunjukkan }\end{array} \\
\text { signifikan perubahan } \\
\text { HbA1c, tapi tidak ada } \\
\text { perubahan signifikan } \\
\text { dalam kualitas hidup dan } \\
\text { kegiatana perawatan diri. }\end{array}$ & $\begin{array}{l}\text { Glukosa Buddy } \\
\text { terbukti } \\
\text { mengendalikan } \\
\text { diabetes dengan } \\
\text { adaanya } \\
\text { perubahan nilai } \\
\text { HbA1c. }\end{array}$ \\
\hline
\end{tabular}




\section{Implikasi penggunaan dalam asuhan keperawatan}

a. Pengkajian keperawatan

Pengkajian dengan aplikasi memudahkan perawat dalam mengakses informasi pasien dan mengetahui kondisi kesehatannya saat ini (Kuo, Wang \& Chen, 2015). Data yang didapat bisa sangat terperinci dan jujur. Pasien dapat mengungkapkan seluruh yang dirasakannya dengan mengunakan aplikasi ini tanpa perlu perawat dan tenaga kesehatan lainnya melakukan pemeriksaan fisik, contoh fluktuasi kadar glukosa darah pasien bisa tergambar selama 1 minggu.

\section{b. Diagnosis Keperawatan}

Dari data yang terkumpul di aplikasi setiap harinya, perawat dapat membuat prioritas masalah kemudian diagnosa utama yang ada pada pasien, misalnya resistensi insulin dan obesitas.

c. Intervensi Keperawatan

Perawat dapat merencanakan intervensi apa yang akan dilakukan pasien secara mandiri di rumah, hanya dengan melalui ponsel. Intervensi lebih terfokus, dapat dilakukan, dan pasien ingin melakukan sehungga terjadi perubahan perilaku untuk mempertahankan kadar glukosa darah. Dengan aplikasi ini promosi kesehatan dan deteksi dini komplikasi diabetes dapat diidentifikasi sendiri, dengan perencanaan pemantauan yang mengidentifikasikan kearah awalnya terjadi komplikasi misalnya terjadi luka pada kaki.

Menurut Standar Intervensi Keperawatan Indonesia (SIKI), intervensi yang dilakukan adalah mengembangkan strategi bersama pasien untuk meningkatkan kepatuhan regimen obat, pemantauan nutrisi dari berat badan pasein, diet, monitor kalori, serta cek gula darah. Intervensi tersebut dapat dilakukan dengan menggunakan salah satu aplikasi seperti Glukosa buddy. Bahkan, intervensi perawat secara langsung pasien kapan saja, tanpa harus datang ketempat yang jauh dan memandirikan pasien.

\section{SIMPULAN}

Beragam manfaat yang ditawarkan dari aplikasi ponsel atau web yang tersedia merupakan salah satu solusi untuk meningkatkan derajat kesehatan pasien diabetes di masa adaptasi kebiasaan baru. Pasien diabetes yang merupakan penyakit kronis dan berisiko tinggi terinfeksi memerlukan ketaatan dalam manajemen perawatan diabetes dan hal ini ditawarkan oleh aplikasi kesehatan melalui ponsel . Bahkan aplikasi ini telah diuji dalam memonitoring dan mengedukasi pasien (David dan Raifullah, 2016). Dengan adanya aplikasi ponsel atau web mengenai diabetes, baik pasien dan perawat dapat memantau ketaatan perilaku, mengontrol 
kadar glukosa darah, diet, aktifitas fisik, mengedukasi, pengobatan dan konsultasi dengan tenaga kesehatan. Penggunaan aplikasi ini diharapkan dapat meminimalisir kontak pasien dengan infeksi Covid-19.

Aplikasi gratis yang bisa didapat diponsel pintar seperti Glukosa buddy bisa menjadi alternatif sementara sebelum aplikasi ponsel yang akan dikembangkan nantinya. Penulis melihat di Indonesia sendiri telah diluncurkan aplikasi "Teman Diabetes" dan "Sahabat Diabetes" sebaai sistem pendukung pasien diabetes, bahkan Perkumpulan Endokrinologi Indonesia (PERKENI) telah meluncurkan aplikasi ponsel Diabetes Enhancement for Unggaged Partnership (DEEP). DEEP yang diluncurkan 2019 membantu tenaga kesehatan memonitor keadaan pasien diabetes. Namun infrastruktur, sosialisai terkait pengguanaan fitur-fitur aplikasi ini penting untuk di update agar pasien dan tenaga kesehatan dapat menggunakannya dengan tepat, mudah dan efisien.

Penerapan aplikasi ini nantinya dapat mengorganisir informasi kesehatan yang diberikan pasien, memperkuat hubungan tenaga medis dan manajemen pusat akan pelayan pasien diabetes sehingga mendukung program departemen kesehatan. Karena dimasa mendatang menyediakan dukungan untuk kesehatan pasien terus menerus dapat menjadi tugas yang menantang dan membutuhkan infrastruktur dan personel dalam menggunakan ponsel untuk peningkatan informasi kesehatan yang memadai (David dan Rafiullah, 2016).

\section{UCAPAN TERIMA KASIH}

Ucapan terima kasih diberikan penulis kepada pihak BUDI LPDP dan Kemenristek yang telah memberikan dukungan sehingga artikel ini dapat tersusun dengan baik.

\section{DAFTAR RUJUKAN}

Beran, D., Perone, S. A., Perolini, M. C., Chappuis, F., Chopard, P., Haller, D. M., ... \& Gastaldi, G. 2020. Beyond the virus: Ensuring continuity of care for people with diabetes during COVID19. Primary Care Diabetes.

Block, G., Azar, K. M., Romanelli, R. J., Block, T. J., Hopkins, D., Carpenter, H. A., ... \& Block, C. H. 2015. Diabetes prevention and weight loss with a fully automated behavioral intervention by email, web, and mobile phone: a randomized controlled trial among persons with prediabetes. Journal of medical Internet research, 17(10), e240

Block, G., Azar, K. M., Romanelli, R. J., Block, T. J., Hopkins, D., Carpenter, H. A., ... \& Block, C. H. 
2015. Diabetes prevention and weight loss with a fully automated behavioral intervention by email, web, and mobile phone: a randomized controlled trial among persons with prediabetes. Journal of medical Internet research, 17(10), e240

Brzan, P. P., Rotman, E., Pajnkihar, M., \& Klanjsek, P. 2016. Mobile applications for control and self management of diabetes: a systematic review. Journal of medical systems, 40(9), 210

Carroll AE, DiMeglio LA, Stein S, Marrero DG. 2011. Contracting and monitoring relationships for adolescentswith type 1 diabetes: a pilot study. DiabetesTechnol Ther.

Chen L, Chuang L-M, Chang C-H et al. 2013. Evaluating self-management behaviors of diabetic patients in a telehealthcare program: longitudinal study over 18 months. J Med Internet Res.

David. S.K, Rafiullah. M. R. M. 2016. Innovation health inforamtic as an effective modern strategy in diabetes managemen: a critical review. Int J Clin Pract

Gund, A., Sjöqvist, B. A., Wigert, H., Hentz, E., Lindecrantz, K., \& Bry, K. 2013. A randomized controlled study about the use of eHealth in the home health care of premature infants. BMC medical informatics and decision making, 13(1), 22.

Guo, S. H. M., Chang, H. K., \& Lin, C. Y. 2015. Impact of Mobile Diabetes
Self-Care System on patients' knowledge, behavior and efficacy. Computers in Industry, 69, 22-29.

Hee-Sung K. 2007. Impact of web-based nurse's education on glycosylated haemoglobin in type 2 diabetic patients. J Clin Nurs

Houston, S, M etc, 2015. An Introduction Nursing Informatics Evolution \&innovation. By Taylor \& Francis Group. LLc. CCr Press https://daily.oktagon.co.id/teknolog i-dan-akses-kesehatan-diindonesia-sudahkah-mapan/

International Diabetes Federation. 2011. IDF. Diabetes Atlas,. (5th ed). Brussels, Belgium: International Diabetes Federation.

Kim H-S, Jeong H-S. 2007. A nurse short message service by cellular phone in type-2 diabetic patients for six months. J Clin Nurs

Kirwan, M., Vandelanotte, C., Fenning, A., \& Duncan, M. J. 2013. Diabetes self-management smartphone application for adults with type 1 diabetes: randomized controlled trial. Journal of medical Internet research, 15(11), e235.

\section{Kumar S, Wang E-H, Pokabla MJ, Noecker RJ. 2012. Teleophthalmology assessment of diabetic retinopathy fundus images: smartphone versus standard office computer workstation. Telemed e-Health}

Kuo, M. H., Wang, S. L., \& Chen, W. T. 2016. Using information and mobile technology improved elderly home care services. Health 
Policy and Technology, 5(2), 131142.

Larsen ME, Turner J, Farmer A, Neil A, Tarassenko L. 2010.Telemedicinesupported insulin optimisation in primary care. $\mathrm{J}$ Telemed Telecare.

Lewis. Dirksen, Heitkemper, Bucher \& Camera. 2014. Medical Surgical Nursing. Assesment \& Management of clinical Problems, 8th Ed. USA: elsevier

Menkes. 2016. Mari Kita Cegah diabetes Dengan Cerdik (7April2016) http://www.depkes.go.id/article/pri nt/16040700002/menkes-mari-kitacegah-diabetes-dengancerdik.html\#

Muralidharan, S., Ranjani, H., Anjana, R. M., Allender, S., \& Mohan, V. 2017. Mobile Health Technology in the Prevention and Management of Type 2 Diabetes, 334-341. https://doi.org/10.4103/ijem.IJEM

Nes AA, vanDulmen S, Eide E et al. 2012. The development and feasibility of a web-based intervention with diaries and situational feedback via smartphone to support selfmanagement in patients with diabetes type 2. Diabetes Res Clin Pract

Paré, G., \& Kitsiou, S. 2017. Methods for literature reviews. In Handbook of eHealth Evaluation: An Evidencebased Approach [Internet]. University of Victoria..

Pranoto, A. 2006. DM di Indonesia, Permasalah dan Penatalaksanaannya. Seminar Lili National Confrence, Solo 12.
Pusat Data dan informasi KementrianKesehatan RI. 2015. Info Datin. Jakarta http://www.depkes.go.id/resources/ download/pusdatin/infodatin/infod atin-diabetes.pdf

Riset Kesehatan Dasar. 2013. Badan Penelitian dan Pengembangan Kesehatan. Jakarta: Kementerian Kesehatan Republik Indonesia.

Rossi MCE, Nicolucci A, Pellegrini F et al. 2009. Interactive diary for diabetes: a useful and easy-to-use new telemedicine system to support the decision-making process in type 1 diabetes. Diabetes Technol Ther

Rossi, M. C., Nicolucci, A., Lucisano, G., Pellegrini, F., Di Bartolo, P., Miselli, V., ... \& Vespasiani, on behalf of the DID Study Group, G. 2013. Impact of the "Diabetes Interactive Diary" telemedicine system on metabolic control, risk of hypoglycemia, and quality of life: a randomized clinical trial in type 1 diabetes. Diabetes technology \& therapeutics, 15(8), 670-679.

The Daily Oktagon. 2017. Teknologi dan Akses Kesehatan di Indonesia. Jakarta

Tim Pokja SIKI DPP PPNI. 2018. Standar Intervensi Keperawatan Indonesia (I). Jakarta. Retrieved from http://www.inna-ppni.or.id

Trigalico interactive. (2011). Daibetes Diary 2011 http://www.tricalico.com/diabetes \%20diary.html 
Warren, R., Carlisle, K., Mihala, G., \& Scuffham, P. A. 2018. Effects of telemonitoring on glycaemic control and healthcare costs in type 2 diabetes: a randomised controlled trial. Journal of telemedicine and telecare, 24(9), 586-595.

WHO. (2016). Diabetes Fakta dan Angka. http://www.searo.who.int/indonesia topics/8-whd2016-diabetes-factsand-numbers-indonesian.pdf

Yoo HJ, Park MS, Kim TN et al. 2009. A ubiquitous chronic disease care system using cellular phones and the internet. Diabet $\mathrm{Med}^{1}$

Zhai YK, Zhu WJ, Cai YL, Sun DX, Zhao J. Clinical- and cost-effectiveness of telemedicine in type 2 diabetes mellitus: a systematic review and metaanalysis. Medicine 2014 Dec;93(28):e312. https://doi.org/10.1097/MD.000000 000000312. 